\title{
Increasing effectiveness of the sewing methods for products with special destination
}

\author{
DOI: $10.35530 / I T .070 .05 .1518$
}

\section{ABSTRACT - REZUMAT}

\section{Increasing effectiveness of the sewing methods for products with special destination}

The execution of the products with special destination requires solving two problems: assuring a high degree of protection of the consumer, acquired by structural and technological design, according with the product destination and increasing the operator's responsibility for the quantitative and qualitative result of the work, by implementing rigorous work methods for the sewing operations. The final result will be economical efficiency of the companies. Paper's aim is to analyze different solutions for the sewing operations for military equipment (for example, products designed to carry grenades or radio stations). The case study was made in a clothing company, with the particularity that, for increasing work responsibility, one operator is responsible for all the operations for a product. The work method used in the paper implied data analyze and synthesis, the results were obtained using the Time Measurement Method. Implementing the optimum work method at the production system level results in decreasing the time for the order, in $100 \%$ quality conditions. The research path used in the paper can be used for obtaining some data used for the evaluation of the results, in order for the clothing companies to be certified for the sewing of the specific products, taking in account that, for this type of products, the firms certification is an European request.

Keywords: sewing operations, protective equipment, Time Measurement Method, life security, handling

\section{Creșterea eficienței metodelor de coasere pentru produsele cu destinație specială}

Executarea produselor cu destinație specială necesită rezolvarea a două probleme: asigurarea unui grad ridicat de protecție a consumatorului, dobândit prin proiectare structurală și tehnologică, în conformitate cu destinația produsului și creșterea responsabilității operatorului pentru rezultatul cantitativ și calitativ al lucrării, prin implementarea unor metode riguroase de lucru pentru operațiile de coasere. Rezultatul final va fi eficiența economică a companiilor. Scopul lucrării este de a analiza diferite soluții pentru operațiile de coasere pentru echipamentele destinate transportului grenadelor și al stațiilor radio. Studiul a fost realizat într-o firmă specializată, având particularitatea că, pentru creșterea responsabilizării muncii, un operator realizează toate operațiile de prelucrare pentru un produs. Metoda utilizată în lucrare implică analiza și sinteza datelor, rezultatele fiind obținute prin metoda MTM (Time Measurement Method). Metoda propusă în lucrare poate fi aplicată și pentru alte operații de coasere sau de tratare umidotermică. Transpunerea metodei de muncă considerată optimă la nivel de sistem de fabricație conduce la diminuarea timpului necesar pentru realizarea la termen a comenzii, în condiții de calitate $100 \%$ a produselor obținute. Soluțiile de îmbunătățire, odată implementate, conduc la formarea de automatisme la realizarea secvențelor de coasere. Pentru obținerea rezultatelor estimate în lucrare este necesară îmbunătățirea disciplinei muncii în cadrul firmei.

Cuvinte-cheie: operaţii de coasere, echipament de protecţie, metoda MTM, securitatea vieții, mânuire

\section{INTRODUCTION}

Being part of the European Union implies for the garment manufacturers a new set of restrictions, more and more complex, aiming not only the physical elements of the garments but also the security of the customer's life. Approaching these European problems constitutes for the manufacturers a system of objectives, priorities and instruments, their applicability being a problem of know how transfer, industrial culture and financial resources.

One of the fields that imply the use of these proceedings is constitute by the products for equipments designed to carry grenades or radio stations (figure 1). From the conceptual point of view this type of products must answer the standard functions set, the

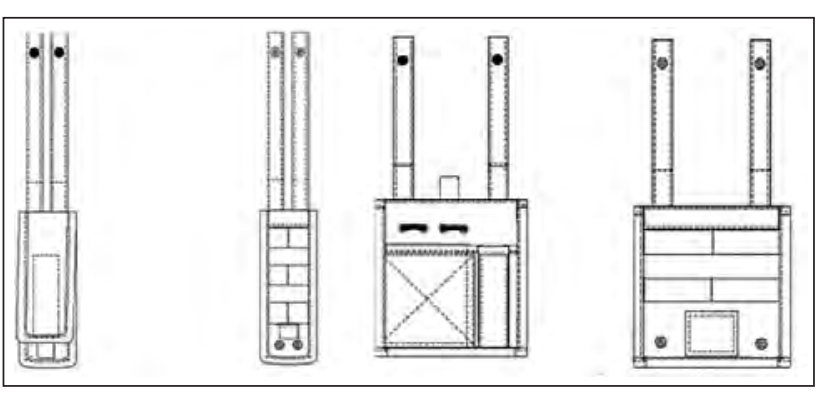

Fig. 1. Equipment for caring grenades or radio stations

differences being in their percentage in the products utility [1]. So, there are important: safety using, functionality and not at last the esthetic function. 
Satisfying the specific functions implies solutions for some technical complex problems, from the designing stage, as following:

- Establishing the proceedings for standard using, for all the customers [2];

- Selecting the raw materials according to the requests, such as: proper behavior at the physical mechanical, stress in using process, superior hygiene characteristics, easy maintenance, attractive color [3-4];

- Selecting the auxiliary materials: tapes, buckles, snaps, Velcro etc. on different criteria as for the clothing products. So, if at the classical products the option is based mainly on the price and aspect, at the products with special destination, the main function is the life security [5];

- The peculiar technical solutions for some of the products functions, materialized by the patterns and technological design [6].

From technical point of view, the following aspects are important:

- Technologies with a high degree of interdependence, with well established following preceding: for example manufacturing group $\mathrm{z}$ is preceded by group $\mathrm{y}$, and its development is conditioned by manufacturing group $\mathrm{x}$;

- Intensive technologies, involving a large number of equipment and methods (established by a decisional process) for every type of product, the combination between these being correlated with the type of the intelligent function (like visibility, communication, sealing).

From the optional criteria point of view, the technologies can be:

- Basic technologies, including the equipment and knowledge compulsory for a product or process, containing documentations, operation specifications, execution schemes, prototypes;

- Unspecific technologies for a product or process, that are the same for every process or product, necessary for manufacturing activity or for knowledge generating (sub components execution plans).

For protective garments it is very important to know and respect these criteria, because of the complexity of this equipment functions and their "hybrid" structure. So, both the basic and unspecific technologies can be traditionally or up to date. Based on the hypothesis that in technological design are always more than one variant for product manufacturing, the accent should be put from just drawing the technological processes to a rational approach, in strong connection with the destination. So, depending on the body area that must be protected, if its exposure to the risk factor varies on the body, the protective function has different dimensional levels and the functional structure of the constitutive elements of the product is different. The garment's functional elements are, at their level, composed of cut pieces, well defined by the characteristics of the raw materials and by their shape [7].
This paper analyzes the case of the classic technological solutions for grenade caring equipment. This paper's objective is to identify solutions for decreasing the time for these types of equipment production.

\section{RESEARCH PATH}

In order to solve the papers' objective, the following steps are followed:

1. General structiure identification of the production system for the studied products (figure 2).

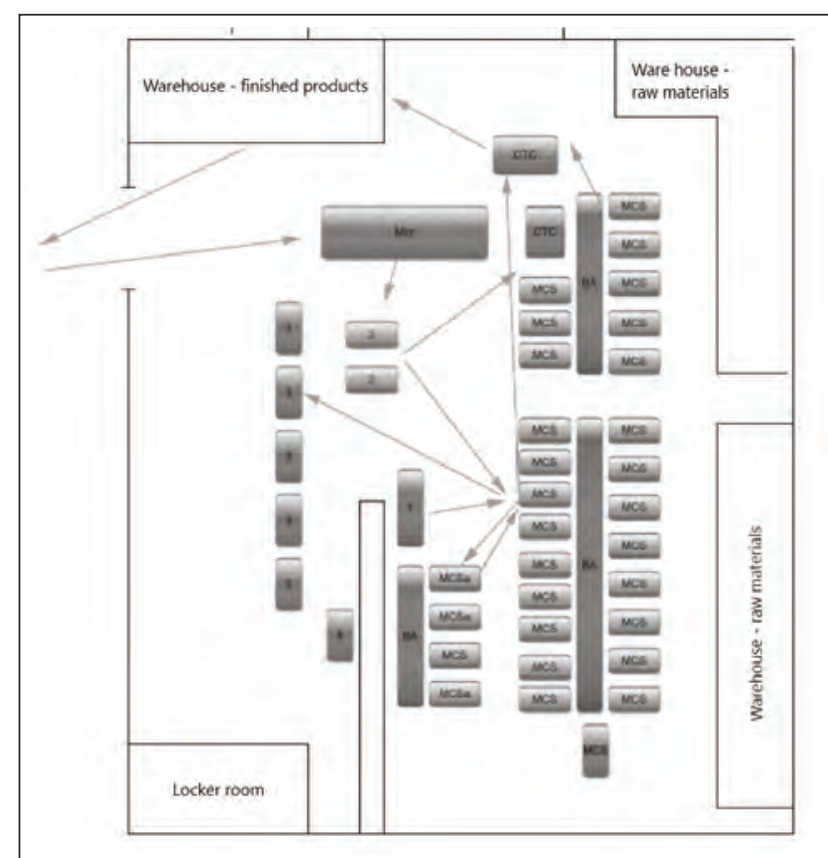

Fig. 2. General structure of the production system for the studied products

2. Sewing operations for the studied products. A sequence of the studied operation is presented in table 1.

3. The analyze of the selected sewing operations reveals the following:

- The operators execute all the operations for one product, in this way increasing the work responsibility, for $100 \%$ quality products.

- The time for the same operations varies from one operator to another (the timing is based on an average of the operation time, from 4 workers, the operators do not depend on the previous or next operation).

- The handling of the sewing parts is difficult, due to the stiffness of the materials, of different structures (PVC impregnated materials, supporting tapes, metallic rings, Velcro) and the different number of layers, leading to variation of the operational times for the same task.

- The frequent needle break affects the time rate, depending on the operator's handling ability (numerous back tacking at the beginning and end of the sewing line).

- Significant differences are at the picking up phase of the sewing operations. The analyzed work places are presented in table 2. 


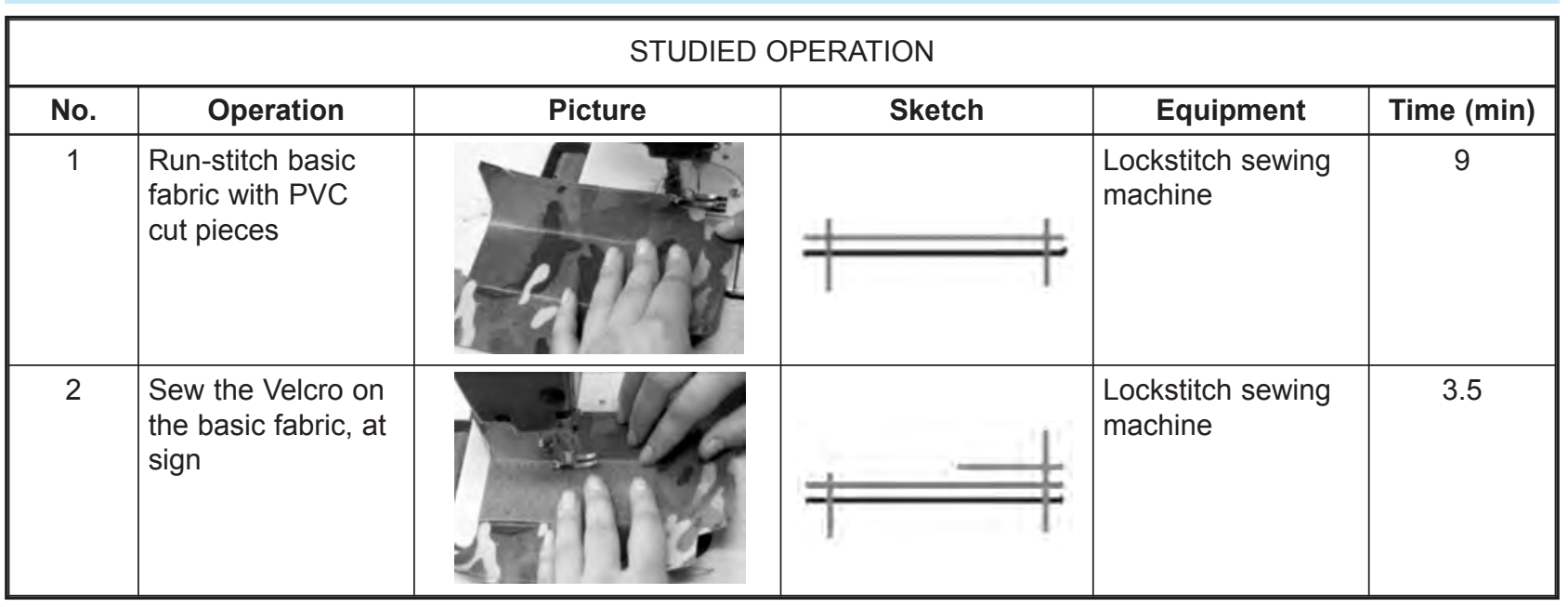

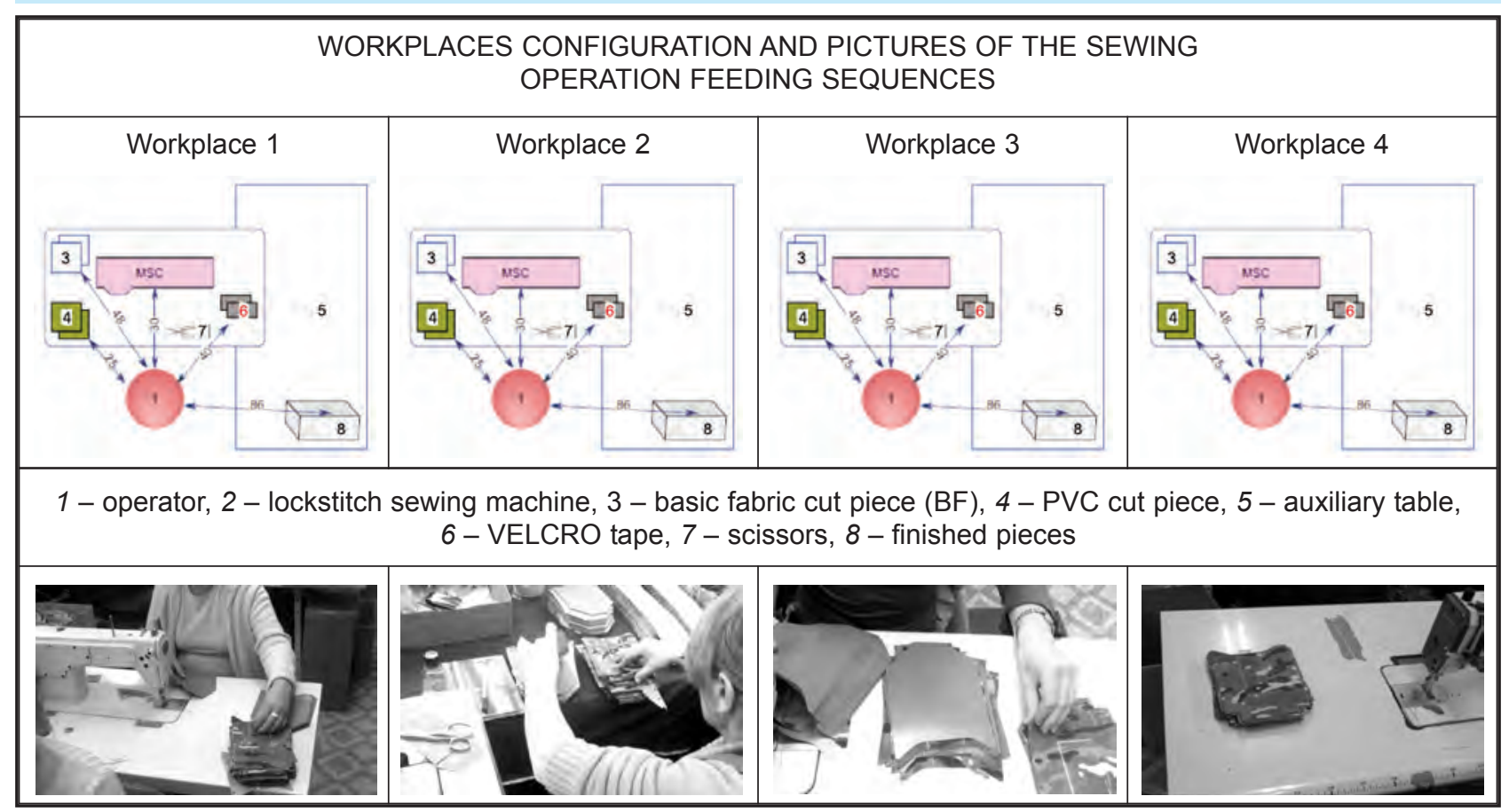

4. Analyze and evaluation of the picking up and placing under the pressing foot of the cut piece of basic fabric and the cut piece of PVC material. The analyze was made at four workplaces. The results (work method and MTM estimations [8]) of the feeding sequence of the sewing operation analyze are presented in table 3 .

Table 3

\begin{tabular}{|c|c|}
\hline \multicolumn{2}{|c|}{ RESULTS OF THE FEEDING SEQUENCE OF THE SEWING OPERATION } \\
\hline $\begin{array}{l}\text { Operator 1: } \\
\text { Preparing the workplace: } \\
\text { Placing the cut pieces of basic fabric (BF) bundle on the } \\
\text { right side of the machine table, } \\
\text { Placing the cut pieces of PVC material bundle on the } \\
\text { right side of the machine table, } \\
\text { Placing the box with the Velcro tape on the right side } \\
\text { Placing some of the Velcro tapes on the right side, under } \\
\text { the back tacking lever, } \\
\text { Placing the scissors on the machine table, } \\
\text { Placing the box for the finished pieces on the left side, } \\
\text { near the chair. }\end{array}$ & $\begin{array}{l}\text { Operator 2: } \\
\text { Preparing the workplace: } \\
\text { Placing the cut pieces of basic fabric bundle on the right } \\
\text { side, on the auxiliary table, } \\
\text { Placing the cut pieces of PVC material bundle on the } \\
\text { right side, on the auxiliary table, } \\
\text { Placing the box with the Velcro tape on the right side, on } \\
\text { the chair, } \\
\text { Placing the scissors on the machine table, } \\
\text { Placing the box for the finished pieces on the left side, } \\
\text { near the chair. }\end{array}$ \\
\hline
\end{tabular}


Working method:

1. Pick the PVC cut piece with left hand. Place on the machine table, in the sewing area,

2. Pick the basic fabric cut piece with left hand. Place upon the PVC cut piece,

3. Check the cut pieces edges,

4. Place under the presser foot.

Estimation of the operational time using MTM method (for 5 pieces)

\begin{tabular}{|l|l|c|c|}
\hline \multicolumn{1}{|c|}{ Basic motions } & MTM & TMU & $\begin{array}{c}\mathbf{t} \\
\text { (min) }\end{array}$ \\
\hline $\begin{array}{l}\text { 1. Reach the left hand, } \\
\text { grab PVC cut piece, } \\
\text { bring the left hand on } \\
\text { the machine table, } \\
\text { positioning PVC } \\
\text { cut piece }\end{array}$ & $\begin{array}{l}\text { (R25A } \\
\text { G1A M25B } \\
\text { P1SE) } \times 5\end{array}$ & 111.5 & 0.067 \\
\hline $\begin{array}{l}\text { 2. Reach left hand, grab } \\
\text { BF piece, move left } \\
\text { hand on the machine } \\
\text { table }\end{array}$ & $\begin{array}{l}\text { (R48A G1A } \\
\text { M485 }\end{array}$ & 201.5 & 0.121 \\
\hline $\begin{array}{l}\text { 3. Positioning BF piece } \\
\text { on the PVC piece, } \\
\text { arrange the edges }\end{array}$ & (P2NSD & 155.5 & 0.093 \\
\hline $\begin{array}{l}\text { 4. Positining the assam- } \\
\text { bly under the presser } \\
\text { foot }\end{array}$ & P2NSD $\times 5$ & 133 & 0.0798 \\
\hline Total & & 601.5 & 0.3609 \\
\hline
\end{tabular}

\section{Operator 3:}

Preparing the workplace:

Placing the cut pieces of basic fabric bundle on the left side of the machine table,

Placing the cut pieces of PVC material bundle on the right side of the machine table,

Placing the box with the Velcro tape on the right side, on a chair,

Placing some of the Velcro tapes on the right side, under the back tacking lever,

Placing the scissors on right, on the machine table,

Placing the box for the finished pieces on the left side, near the chair.

\section{Working method:}

1. Grab the PVC cut piece with right hand from the machine table,

2. Placing the basic piece on the PVC piece,

3. Arrange the pieces edges. Placing the overlapped pieces on the left side of the machine table,

4. Grab the overlapped pieces,

5. Place under the presser foot.

Estimation of the operational time using MTM method (for 5 pieces)

\begin{tabular}{|c|l|c|c|}
\hline \multicolumn{1}{|c|}{ Basic motions } & MTM & TMU & $\begin{array}{c}\mathbf{t} \\
\text { (min) }\end{array}$ \\
\hline $\begin{array}{l}\text { 1. Reach the right hand, } \\
\text { grab PVC cut piece } \\
\text { bundle, bring the right } \\
\text { hand on the machine } \\
\text { table with the PVC } \\
\text { cut pieces bundle. }\end{array}$ & $\begin{array}{l}\text { R48A G1A } \\
\text { M48B }\end{array}$ & 45,9 & 0,0275 \\
\hline
\end{tabular}

Working method:

1. Pick the basic fabric cut piece with right hand from the auxiliary table,

2. Pick the PVC cut piece with left handauxiliary table,

3. Place the PVC cut piece on the basic fabric. Place on the machine table in the sewing area,

4. Check the overlapped cut pieces edges,

5. Place under the presser foot.

Estimation of the operational time using MTM method (for 5 pieces)

\begin{tabular}{|l|l|c|c|}
\hline \multicolumn{1}{|c|}{ Basic motions } & MTM & TMU & $\begin{array}{c}\mathbf{t} \\
\text { (min) }\end{array}$ \\
\hline $\begin{array}{l}\text { 1. Reach right hand with } \\
\text { body rotation and } \\
\text { pieces visualisation, } \\
\text { grab BF piece, bring } \\
\text { right hand on the } \\
\text { machine table, posi- } \\
\text { tioning the piece }\end{array}$ & $\begin{array}{l}\text { (R1A }(80+6) \mathrm{A} \\
\mathrm{M}(80+6) \mathrm{B}\end{array}$ & 302.5 & 0.1815 \\
\hline $\begin{array}{l}\text { 2. Reach left hand, grab } \\
\text { PVC cut piece, move } \\
\text { left hand on the } \\
\text { machine table }\end{array}$ & (R79A G1A & 261 & 0.1566 \\
\hline $\begin{array}{l}\text { 3. Positioning basic piece } \\
\text { on the PVC piece }\end{array}$ & $\mathrm{P} 2 \mathrm{NSD} \times 5$ & 133 & 0.0798 \\
\hline 4. Arrange the edges & $\mathrm{P} 2 \mathrm{NSD} \times 5$ & 133 & 0.0798 \\
\hline $\begin{array}{l}\text { 5. Positining the assam- } \\
\text { bly under the presser } \\
\text { foot }\end{array}$ & $\mathrm{P} 2 \mathrm{NSD} \times 5$ & 133 & 0.0798 \\
\hline Total & & 962.5 & 0.5775 \\
\hline
\end{tabular}

\section{Operator 4:}

\section{Preparing the workplace:}

Placing the cut pieces of PVC material bundle on the right side, on the auxiliary table,

Placing the cut pieces of basic fabric bundle on the left side, on the machine table,

Placing the box with the Velcro tape on the right side, on the chair,

Placing some of the Velcro tapes on the right side, under the back tacking lever,

Placing the scissors on the machine table,

Placing the box for the finished pieces on the right side, near the chair.

\section{Working method:}

1. Grab the PVC cut piece with right handauxiliary table,

2. Grab the basic fabric cut piece with left hand,

3. Place the PVC cut piece on the basic fabric,

4. Check the overlapped cut pieces edges,

5. Place under the presser foot.

Estimation of the operational time using MTM method (for 5 pieces)

\begin{tabular}{|c|c|c|c|}
\hline \multicolumn{1}{|c|}{ Basic motions } & \multicolumn{1}{|c|}{ MTM } & TMU & $\begin{array}{c}\mathbf{t} \\
\text { (min) }\end{array}$ \\
\hline $\begin{array}{l}\text { 1. Reach right hand with } \\
\text { body rotation and } \\
\text { pieces visualisation, } \\
\text { grab PVC piece, bring } \\
\text { the right hand on the } \\
\text { machine table. }\end{array}$ & $\begin{array}{l}\text { (R79A G1A } \\
\text { M79B }) \times 5\end{array}$ & 255 & 0,153 \\
\hline
\end{tabular}




\begin{tabular}{|c|c|c|c|c|c|c|c|}
\hline \multirow[t]{2}{*}{$\begin{array}{l}\text { 2. Reach left hand with } \\
\text { the PVC pieces bundle, } \\
\text { grab PVC pieces } \\
\text { bundle, arrange the } \\
\text { PVC bundle in } \\
\text { cascade, grab PVC } \\
\text { piece with left hand. }\end{array}$} & \multirow[t]{2}{*}{$\begin{array}{l}\text { R2A G1A } \\
\text { P2SE }\end{array}$} & \multirow[t]{2}{*}{20,2} & \multirow[t]{2}{*}{0.0121} & $\begin{array}{l}\text { 2. Reach left hand to the } \\
\text { basic fabric bundle, } \\
\text { grab basic fabric cut } \\
\text { piece, move left hand } \\
\text { and posision it over } \\
\text { the PVC piece. }\end{array}$ & $\begin{array}{l}(\text { R35B G1A } \\
\text { M35A } \\
\text { P1SE }) \times 5\end{array}$ & 180,5 & 0.1566 \\
\hline & & & & \multirow{2}{*}{$\begin{array}{l}\text { 3. Arrange the edges of } \\
\text { basic and PVC fabric } \\
\text { cut pieces. }\end{array}$} & \multirow[b]{2}{*}{ P2NSD } & \multirow[b]{2}{*}{26.6} & \multirow[b]{2}{*}{0.0159} \\
\hline \multirow{2}{*}{$\begin{array}{l}\text { 3. Bring the PVC piece on } \\
\text { the machine table, } \\
\text { releace the PVC piece }\end{array}$} & \multirow{2}{*}{$\begin{array}{l}(\mathrm{M} 2 \mathrm{~B} \text { RL1) } \\
\times 5\end{array}$} & \multirow{2}{*}{20} & \multirow{2}{*}{0.0012} & & & & \\
\hline & & & & \multirow{2}{*}{$\begin{array}{l}\text { 4. Positining the } \\
\text { assambly under the } \\
\text { presser foot. }\end{array}$} & \multirow[b]{2}{*}{ P2NSD × 5} & \multirow[b]{2}{*}{133} & \multirow[b]{2}{*}{0.0798} \\
\hline \multirow{3}{*}{$\begin{array}{l}\text { 4. Reach left hand to the } \\
\text { machine table, grab } \\
\text { basic fabric piece, } \\
\text { bring and overlap with } \\
\text { PVC piece. }\end{array}$} & \multirow{3}{*}{$\begin{array}{l}(\text { R25A } \\
\text { G1A } \\
\text { M25B } \\
\text { P1SE }) \times 5\end{array}$} & \multirow{3}{*}{139,5} & \multirow{3}{*}{0.0837} & & & & \\
\hline & & & & Total & & 595 & 0.3571 \\
\hline & & & & & & & \\
\hline $\begin{array}{l}\text { 5. Grab the bundle with } \\
\text { PVC and basic fabric } \\
\text { pieces overlapped with } \\
\text { both hands and arrange } \\
\text { the bundle, rich the left } \\
\text { hand with the bundle } \\
\text { and place it on } \\
\text { machine table, left side }\end{array}$ & $\begin{array}{l}\text { G1B } \\
\text { P2NSD } \\
\text { M25B } \\
\text { P1SE }\end{array}$ & 47,5 & 0.0285 & & & & \\
\hline $\begin{array}{l}\text { 6. Reach left hand, grab } \\
\text { basic fabric and PVC } \\
\text { pieces, bring to sewing } \\
\text { area. }\end{array}$ & $\begin{array}{l}(\mathrm{R} 25 \mathrm{~A} \text { G1 } \\
\mathrm{M} 25 \mathrm{~B}) \times 5\end{array}$ & 111,5 & 0,0669 & & & & \\
\hline $\begin{array}{l}\text { 7. Positining the assambly } \\
\text { under the presser foot. }\end{array}$ & $\mathrm{P} 2 \mathrm{NSD} \times 5$ & 133 & 0.0798 & & & & \\
\hline Total & & 601,5 & 0,23609 & & & & \\
\hline
\end{tabular}

\section{RESULTS}

The study reveals the following:

a. After the MTM evaluation of the picking up the cut pieces and placing under the foot, at the four workplaces, it can be noticed that the operator from the workplace no. 3 has the best method (minimum time). This method should be extrapolated to the entire operation and to all the 27 sewing machines from the sewing room.

b. Analyzing the feeding phase of the sewing operation of the basic fabric with the PVC material cut pieces, some other improving solutions can be suggested:

b.1. repositioning the bundles with the basic fabric and PVC material cut pieces,

b.2. changing the positioning way for the basic fabric and PVC cut pieces on the machine table at the feeding sequence of the sewing operation.

b.3. changing the sewing method:

- chain sewing (50 pieces), first the right side, with picking up simultaneous the cut pieces from the right side, $10 \mathrm{~cm}$ from the presser foot,

- separation of the sewed pieces (50 pieces),

- chain sewing the left side, placing the bundle at $10 \mathrm{~cm}$ in front of the operator,

- separation of the sewed pieces (50 pieces),
- chain sewing the bottom side, placing the bundle at $10 \mathrm{~cm}$ in front of the operator,

- separation of the sewed pieces (50 pieces). Next, for sewing the Velcro tapes, the bundle with cut tapes must be positioned under the back tacking lever and the bundle with the semi fabricates on the right side, close to the lever. This position allows the pick up, in one move of the right hand, of one Velcro and one semifabricat,

- the eviction of the central element with the Velcro sewed on will be made once at 20-25 overlapped elements, on the left part, at $15 \mathrm{~cm}$,

b.4. replacing the sewing machine with one with thread cutter.

\section{CONCLUSIONS}

Extending the results of the study at the entire company level will decrease the time necessary for getting the order in time, $100 \%$ quality level. The improving solutions, resulted from the work method analyze, implementation lead to:

- Developing of automatism at picking and placing the cut piece under the presser foot;

- Cutting once for 50 pieces, will eliminate the moves of hand reaching for the scissors, bringing the scissors and cutting; 
- No more repositioning of every piece at changing the sewing direction ( 7 repositioning are eliminated for every semi fabricate);
- Training automat motions at methodical placing the elements after sewing and thread cutting.

\section{REFERENCES}

[1] Dulgheriu, I., Avadanei, M., Cozmanciuc, C., Research Concerning the Heat Sealed Treatment parameters Influence on the Main Characteristics of a Doubled Ensemble, In: Tekstil VE Konfeksiyon, 2014, 24, 4, 380-385

[2] Matenciuc, C., Dulgheriu, I., Quality evaluation model for clothing materials, In: Industria Textila, 2011, 62, 2, 99-104

[3] Dulgheriu, I., Cozmanciuc, C., Mechanical tests carried out on composites materials specific to safety jackets, In: Industria Textila, 2012, 63, 2, 97-104

[4] Negru, D., Buhu, L., Dulgheriu, I., Buhu, A., Loghin, E.C., Absorption and moisture transfer through knitted fabrics made of natural and man-made fibers, In: Industria Textila, 2017, 68, 4, 269-274, https://doi.org/10.35530/ IT.068.04.1350

[5] Loghin, C., Nicolaiov, P., et al., Functional design of equipments for individual protection, The $6^{\text {th }}$ International Conference on the Management of Technological Changes, 2009, 2, 693-696

[6] Loghin, C., editor: Îmbrăcăminte funcțională, PIM, ISBN 978-606-520-126-2, lasi, Romania, 2008

[7] Loghin, C., Nicolaiov, P., et al., Work method - Decisional tool for technological change, The $4^{\text {th }}$ International Conference on Management of Technological Changes Book 2, 2005, 53-58

[8] Loghin, C., Nicolaiov, P., Configurarea locurilor de muncă în confecții, Publisher: Performantica, ISBN 978-606-685055-1, lasi, Romania, 2013

\section{Authors:}

\section{IRINA IONESCU, ADELA FLOREA, EMIL CONSTANTIN LOGHIN}

Technical University "Gheorghe Asachi” IASI, Faculty of Industrial Design and Business Management, Department: Knitting and Clothing Engineering, lasi, Romania

Corresponding author:

\section{IRINA IONESCU}

e-mail: iirina@tex.tuiasi.ro 